\title{
Pengaruh CR, DER, dan NPM terhadap Harga Saham Pada Trade Service Tahun 2014-2018
}

\author{
Santy $^{1}$, Novita Ira Yanni Purba ${ }^{2}$, Suryani Nduru ${ }^{3}$, Aldi Pratama ${ }^{4}$, Wirda Lilia ${ }^{5}$ \\ 1,2,3,4,5 Jurusan Manajemen Keuangan, Universitas Prima Indonesia, Medan \\ correspondence email: santyhuang7@gmail.com,novitairayanni@gmail.com,ndurusuryani@gmail.com, \\ aldipratama929@gmail.com, liliawirda@ymail.com
}

\begin{abstract}
Abstrak. Penelitian ini memiliki tujuan untuk mengetahui Pengaruh Current Ratio, Debt To Equity Ratio, Net Profit Margin terhadap Harga Saham pada Trade Service And Investment di Bursa Efek Indonesia pada periode 2014-2018. Data yang digunakan bersumber dari data di Bursa Efek Indonesia melalui www.idnfinancials.com ${ }_{2}$ dan telah dilakukan seleksi berdasarkan kriteria yang ditentukan. Penelitian ini diharapkan agar dapat menjadi suatu ilmu pengetahuan untuk membantu para peneliti selanjutnya dan juga para mahasiswa atau masyarakat umum yang membutuhkan suatu sumber informasi. Dari penelitian dapat diketahui bahwa Current ratio, Debt to equity ratio secara parsial berpengaruh dan mengalami signifikan terhadap harga saham. Net profit margin secara parsial tidak berpengaruh dan tidak mengalami signifikan terhadap harga saham pada Trade service and investment. Tetapi semua variabel berpengaruh secara simultan.
\end{abstract}

Kata Kunci: Current Ratio; Debt to Equity Ratio; Net Profit Margin; Harga Saham

\begin{abstract}
This research has objective to know the influence of current ratio, debt to equity ratio, net profit margin on the price of shares in the trade and investment service at the Indonesian stock exchange in the period of 2014-2018. The data used sourced from the data at the Indonesian stock exchange through www.idnfinancials.com, and has been done selection based on set criteria. This research is expected to allow can be a science to help the researchers next and also students or people who needs a source of information. From the research it can be seen that the Current ratio, Debt to equity ratio partially influences and experiences a significant effect on stock prices. Net profit margin partially has no effect and does not experience a significant effect on stock prices on Trade service and investment. But all variables affect simultaneously.
\end{abstract}

Keywords: Current Ratio; Debt to Equity Ratio; Total Asset Turnover; Net Profit Margin; Stock Price

\section{PENDAHULUAN}

Di era globalisasi saat ini perkembangan dalam berbagai sektor terus meningkat seiring berjalannya waktu, beragam lokasi wisata serta kebudayaan yang dapat ditemukan di Indonesia sehingga menjadi daya tarik bagi pengunjung lokal maupun asing untuk berkunjung serta mengembangkan pariwisata di Indonesia. Banyaknya wisatawan asing ataupun pendatang dari Indonesia sendiri yang membutuhkan sarana tempat tinggal sementara waktu atau hotel untuk tempat beristirahat. Dengan seiringnya perkembangan zaman, hotel tidak hanya sebagai tempat beristirahat tetapi juga ada beberapa fasilitas yang disediakan untuk melakukan pertemuan bisnis, pelatihan, seminar dan lainnya. Hotel juga bukan hanya sebuah gedung tempat penginapan tetapi juga penyedia restaurant untuk makanan para tamu sebagai bentuk service dari hotel itu sendiri. Hotel juga memiliki peranan penting dalam pembangunan negara karena dapat membantu dalam meningkatkan usaha pendidikan ataupun latihan, meningkatkan devisa dan pendapatan negara dan juga meningkatkan hubungan Indonesia dengan negara lain. Sektor ini juga sangat berpengaruh di Indonesia, karena sektor ini dapat memenuhi kebutuhan konsumen dalam bentuk pelayanan ataupun jasa. Sektor trade service and investment merupakan perusahaan yang dimana sektornya sangat dekat dengan kehidupan sosial manusia dan mudah di akses dan dijumpai di berbagai daerah sehingga itu menjadi alasan kami melakukan penelitian pada sub sektor tourism, restaurant and hotel.

Bursa Efek Indonesia merupakan penyedia sistem dan sarana untuk melakukan penawaran jual beli aset kepada pihak lain dengan tujuan memperdagangkan saham suatu perusahaan. Perkembangan pasar modal di Indonesia terus meningkat karena banyaknya minat investor asing yang masuk, dengan adanya sistem tersebut maka para investor dapat melakukan investasi sesuai dengan karakteristik perusahaan yang di inginkan.

Perusahaan yang sudah go public sangat mudah di akses datanya, yang sangat penting bagi para investor untuk menentukan perusahaan yang akan dipilih untuk ditanamkan modal, seperti memperhatikan Current ratio dalam perusahaan yaitu perbandingan antara aktiva lancar dengan hutang lancar perusahaan. Rasio ini digunakan untuk melihat kemampuan perusahaan dalam membayar kewajiban yang dimiliki dalam waktu jangka pendek. Yang kemudian akan memperlihatkan tingkat keamanan kreditor atau kemampuan perusahaan dalam membayar hutang perusahaan.

Hutang didalam suatu perusahaan harus diperhatikan, karena menjadi pertimbangan bagi para investor dalam menentukan keputusan investasi dalam rasio solvabilitas (Debt to Equity Ratio) karena besar 
kecilnya debt to equity ratio akan menunjukkan kemampuan perusahaan dalam membayar kewajiban perusahaan melalui modal.

Net Profit Margin atau Marjin Laba Bersih adalah rasio profitabilitas yang digunakan sebagai pengukur persentase laba bersih pada suatu perusahaan terhadap penjualan bersih. Marjin Laba Bersih juga menunjukan proporsi penjualan yang tersisa setelah dikurangi semua biaya terkait.

Harga saham adalah nilai sekarang dari arus kas yang akan diterima oleh pemilik saham dikemudian hari. Harga saham merupakan harga yang muncul sebagai hasil dari pergerakan penawaran dan permintaan yang muncul di bursa efek terhadap saham bersangkutan. Semakin tinggi harga saham suatu perusahaan maka akan sebaik pula nilai atau citra perusahaan tersebut dan begitu juga sebaliknya. Naik dan turunnya harga saham akan terkait erat dengan naiknya dan turunnya nilai perusahaan dipasar saham secara umum, dunia bisnis makro dan mikro secara khusus.

Setelah penelitian dapat diketahui bahwa PT Pembangunan Graha Lestari Indah TBK pada tahun 2017-2018, Current Ratio mengalami kenaikan sebesar 2,8 kali. Namun, harga saham mengalami kenaikan sebesar 123 atau 79,35\%. PT Fast Food Indonesia TBK pada tahun 2015-2016, Debt to Equity Ratio mengalami kenaikan sebesar 1,03 kali. Namun, harga saham mengalami kenaikan sebesar 350 atau 30,43\%. Namun, harga saham mengalami kenaikan sebesar 106 atau 37,85\%. PT Hotel Sahid Jaya International TBK pada tahun 2015-2016, Net Profit Margin mengalami kenaikan sebesar 2,13 kali. Namun, harga saham mengalami kenaikan sebesar 350 atau 64,22\%.

Menurut Darsono dan Ashari (2005) Current ratio adalah rasio yang mengukur aktiva lancar sebuah perusahaan dalam memenuhi kewajiban jangka pendek dengan aktiva yang dimiliki. Menurut Brigham dan Houston (2009), Current ratio merupakan rasio likuiditas yang menunjukkan sampai sejauh apa kewajiban lancar ditutupi oleh aset yang diharapkan akan di konversi menjadi kas dalam waktu dekat. Menurut Kasmir (2014) Current ratio merupakan rasio untuk mengukur kemampuan perusahaan dalam membayar kewajiban jangka pendek atau hutang yang segera jatuh tempo pada saat ditagih secara keseluruhan. H1 : Current ratio berpengaruh terhadap Harga saham

Menurut Joel G. Siegel dan Jae K. Shim (2008) dalam buku Fahmi (2016) Debt to equity ratio merupakan ukuran yang dipakai dalam menganalisis laporan keuangan untuk memperlihatkan besarnya jaminan yang tersedia untuk kreditor. Menurut samsul (2006) Debt to equity ratio merupakan rasio yang menunjukkan kemampuan perusahaan dapat mengembalikan hutang jangka panjangnya atau dapat juga diartikan sebagai rasio yang menggambarkan perbandingan antara total hutang dan ekuitas. Menurut patriawan (2011) Debt to equity ratio merupakan rasio yang mengukur besarnya yang hutang dapat ditutupi oleh modal sendiri.

$\mathrm{H} 2$ : Debt to equity ratio berpengaruh terhadap Harga saham

Menurut Hanafi dan Halim (2007), menjelaskan Net Profit margin merupakan rasio yang menghitung sejauh mana kemampuan perusahaan menghasilkan laba bersih pada tingkat penjualan tertentu. Menurut Joel G. Siegel dan Jae K. Shim (2008) dalam buku Fahmi (2016) margin laba bersih sama dengan penjualan bersih. Hal Ini menunjukkan kestabilan kesatuan untuk menghasilkan perolehan pada tingkat penjualan khusus. Dalam Menurut Hanafi dan Halim (2017) Net profit margin merupakan rasio yang menghitung kemampuan perusahaan menghasilkan laba bersih pada tingkat penjualan tertentu.

$\mathrm{H} 3$ : Net profit margin ratio berpengaruh terhadap Harga saham

Menggunakan metode penelitian kuantitatif. Data dalam penelitian ini adalah data sekunder yang dipublikasikan oleh Bursa Efek Indonesia. Jenis penelitian adalah deskriptif.

Populasi dalam penelitian adalah perusahaan Trade Service and Investment yang ada di Bursa Efek Indonesia dan laporan keuangan yang digunakan bersumber dari www.idnfinancials.com. Berdasarkan populasi yang sudah ditentukan terdapat 26 perusahaan.

Sampel adalah bagian dari populasi yang diambil sesuai dengan kriteria yang peneliti temukan. Dalam penelitian ini, teknik sampling yang digunakan adalah metode sampling purposive. Yang terdaftar di Bursa Efek Indonesia selama periode 2014-2018, dan memiliki laba positif, terdapat 12 perusahaan yang memenuhi syarat sebagai sampel dalam penelitian ini

\section{METODE Sampel Penelitian}

Tabel 1. Sampel Penelitian

\begin{tabular}{clc}
\hline No & \multicolumn{1}{c}{ Sektor } & Jumlah \\
\hline 1 & $\begin{array}{l}\text { Perusahaan Trade Service and investment } \\
\text { yang terdaftar di BEI pada periode 2014- }\end{array}$ & \\
& 2618 \\
2 & $\begin{array}{l}\text { Perusahaan Trade Service and investment } \\
\text { yang tidak mempublikasikan laporan }\end{array}$ \\
& keuangannya secara lengkap pada periode \\
& 2014-2018 \\
& $\begin{array}{l}\text { Perusahaan Trade Service and investment } \\
\text { yang tidak menghasilkan laba pada }\end{array}$ \\
& periode 2014-2018 \\
& Total sampel yang diteliti (x periode)
\end{tabular}

Menurut Jogiyanto harga saham adalah harga suatu saham yang terjadi dipasar bursa pada saat tertentu yang dilakukan oleh pelaku pasar dan ditentukan oleh permintaan dan penawaran saham yang bersangkutan 
dipasar modal. Harga saham menjadi indikator keberhasilan manajemen dalam mengelola perusahaannya.

Menurut Fahmi (2016) Current Ratio merupakan rasio untuk mengukur kemampuan perusahaan membayar kewajiban jangka pendek atau utang yang segera jatuh tempo pada saat ditagih secara keseluruhan. Untuk rumus Current Ratio yang digunakan adalah:

Current Ratio $=\frac{\text { Aktiva Lancar }}{\text { Hutang Lancar }}$

Menurut Fahmi (2016) Debt to equity ratio yaitu perbandingan antara total kewajiban (total utang) dengan total modal sendiri. Rumus yang digunakan rumus untuk menghitung Debt to equity ratio yaitu:

Debt to Equity Ratio $=\frac{\text { Total Utang }}{\text { Total Modal Sendiri }}$

Menurut Fahmi (2016) Net profit margin (NPM) merupakan rasio yang digunakan untuk mengukur besarnya persentase laba bersih atas penjualan bersih. Rasio ini dihitung dengan membagi laba bersih terhadap penjualan bersih. Rumus untuk menghitung Net profit margin (NPM) adalah:

Net Profit Margin $=\frac{\text { Laba Bersih Setelah Pajak }}{\text { Penjualan Bersih }}$

\section{Uji Asumsi Klasik}

Uji Normalitas

Menurut Ghozali (2016), uji normalitas digunakan dalam pengujian model regresi, variabel pengganggu atau residual memiliki distribusi normal. Dimana uji $t$ dan f mengasumsi bahwa nilai residual mengikuti distribusi normal. Jika dilanggar maka uji statistik menjadi tidak falid untuk sampel yang kecil.

$$
X^{2}=\Sigma \frac{(0, E)}{E}
$$

Dimana:

X2 : Nilai X2

Oi : Nilai Observasi

Ei : Nilai Expected,interval kelas berdasarkan tabel normal dikali $\mathrm{N}$ (total frekuensi) (pi X N)

$\mathrm{N}$ : Banyaknya angka pada data (total frekuensi)

\section{Uji Multikolinearitas}

Menurut Ghozali (2016), uji multikolinearitas digunakan dalam pengujian model regresi apakah didalamnya terdapat korelasi antar variabel bebas. Dimana model regresi yang baik tidak memiliki korelasi antar variabel bebas. Jika saling berkorelasi maka variabel-variabel ini tidak ortogonal atau nilai korelasi antar variabel bebas sama dengan nol.

Pedoman keputusan berdasarkan nilai VIF (Variance Inflation Factor) : 1. Jika nilai VIF $<10,00$ maka artinya tidak terjadi multikolinearitas dalam model regresi. 2. Jika nilai VIF > 10,00 maka artinya terjadi multikolineartias dalam model regresi.

\section{Uji Autokorelasi}

Menurut Ghozali (2016), uji autokorelasi digunakan dalam pengujian model regresi linear apakah terdapat korelasi antara kesalahan pengganggu pada periode $\mathrm{t}$ dengan kesalahan pengganggu periode $\mathrm{t}-1$. Jika terdapat korelasi maka dikatakan terdapat problem autokorelasi. Masalah ini timbul karena kesalahan pengganggu tidak bebas dari satu observasi ke yang lain.

$$
d=\frac{\sum(e i-e i-1) 2}{\sum e i}
$$

Dimana:

d : nilai durbin Watson

¿ei : jumlah kuadrat sisa

\section{Uji Heteroskedastisitas}

Menurut Ghozali (2016), uji heteroskedastisitas digunakan dalam pengujian model regresi apakah terjadi ketidaksamaan variance dari residual suatu pengamatan ke pengamatan lain. Jika variance nya tetap maka disebut homoskedastisitas dan jika berbeda disebut heteroskedastisitas. Model regresi yang baik adalah homoskedastisitas atau dengan kata lain tidak terjadi heteroskedastisitas. Dasar pengambilan keputusan: 1 . Tidak terjadi heteroskedastisitas, jika nilai t hitung lebih kecil dari t tabel dan nilai signifikansi lebih besar dari 0,05 . 2. Terjadi heteroskedastisitas, jika nilai $t$ hitung lebih besar dari t tabel dan nilai signifikansi lebih kecil dari 0,05 .

\section{Analisis Regresi Linear Berganda}

Metode analisis data penelitian ini menggunakan analisis regresi berganda. Model regresi berganda yang digunakan adalah sebagai berikut:

$$
\begin{aligned}
& \mathrm{Y}=\mathrm{a}+\mathrm{b}_{1} \mathrm{X}_{1}+\mathrm{b}_{2} \mathrm{X}_{2}+\mathrm{b}_{3} \mathrm{X}_{3}+\mathrm{e} \\
& \text { Dimana: } \\
& \mathrm{Y} \quad=\text { Harga Saham } \\
& \text { a } \quad=\text { Nilai konstanta } \\
& \mathrm{b} 1, \mathrm{~b} 2, \mathrm{~b} 3, \mathrm{~b} 4=\text { Koefisien regresi } \\
& \mathrm{X} 1, \mathrm{X} 2, \mathrm{X} 3=\text { Variabel Current Ratio, Debt To } \\
& \text { Equity Ratio, Net Profit Margin } \\
& \mathrm{e}=\text { Presentasi ditolak } 0,05
\end{aligned}
$$

\section{Koefisien Determinasi Hipotesis}

Menurut Ghozali (2016), Koefisien determinasi $\left(\mathrm{R}^{2}\right)$ bertujuan untuk mengukur kemampuan suatu modal menerangkan variasi variabel dependen. Nilainya yakni antara nol dan satu. Jika nilainya kecil berarti variabel independen terbatas dalam menjelaskan variabel dependen. Dan begitu juga dengan sebaliknya.

\section{Pengujian Hipotesis Secara Simultan (uji f)}


Menurut Ghozali (2016), Uji statistik f pada dasarnya bertujuan untuk menunjukkan apakah semua variabel independen mempunyai pengaruh bersamasama terhadap variabel dependen. Dimana hipotesis nol (Ho) tentang tidak adanya pengaruh, umumnya dirumuskan untuk ditolak. Sedangkan hipotesis alternatif (Ha) sebagai hipotesis yang diajukan dalam penelitian ini. Adapun hipotesisnya sebagai berikut: Ho: $b_{1}, b_{2}=0$, artinya tidak ada pengaruh signifikan secara simultan antara variabel independen yaitu Current Ratio dan Debt to Equity Ratio terhadap variabel dependen yaitu harga saham pada trade service and investment periode 2014-2018.

Pengujian Hipotesis Persial (uji t)
Menurut Ghozali (2016), Uji statistik t pada dasarnya bertujuan untuk menunjukkan seberapa jauh pengaruh satu variabel independen secara individual menerangkan variasi variabel dependen. Dimana hipotesis nol (Ho) tentang tidak adanya pengaruh, umumnya dirumuskan untuk ditolak. Sedangkan hipotesis alternatif (Ha) sebagai hipotesis yang diajukan dalam penelitian ini. Adapun hipotesisnya sebagai berikut: Ho: $b_{1}, b_{2},=0$, artinya tidak ada pengaruh signifikan secara parsial antara variabel independen yaitu Current Ratio dan Debt to Equity Ratio terhadap variabel dependen yaitu harga saham pada trade service and investment periode 2014-2018.

\section{HASIL DAN PEMBAHASAN}

Tabel 2. Uji Descriptive Statistcs

Uji Descriptive Statistes

\begin{tabular}{|c|c|c|c|c|c|}
\hline & $\mathrm{N}$ & Minimum & Maximum & Mean & Std. Deviation \\
\hline LN_CR & 60 &,- 3100 & 2,1200 & 695667 & 6037380 \\
\hline LN_DER & 60 & $-1,9800$ & 6700 &,- 688333 & 6239871 \\
\hline LN_NPM & 60 & $-6,1000$ & ,6400 & $-2,608667$ & 1,3332139 \\
\hline LN_HS & 60 & 3,9100 & 8,3700 & 6,311667 & 1,1290752 \\
\hline Valid N (listwise) & 60 & & & & \\
\hline
\end{tabular}

Sumber: Data diolah

Hasil dari uji Descriptive statistics adalah sebagai berikut. A. Variabel LN_CR memiliki sampel 60 dengan nilai minimum $-0,3100$ dan nilai maksimum 2,1200 sedangkan nilai rata-rata 0,695667 dengan standar deviasi 0,6037380. B. Variabel LN_DER memiliki sampel 60 dengan nilai minimum $-1,9800$ dan nilai maksimum 0,6700 sedangkan nilai rata-rata $-0,688333$ dengan standar deviasi 0,6239871. C. Variabel LN_NPM memiliki sampel 60 dengan nilai minimum 6,1000 dan nilai maksimum 0,6400 sedangkan nilai ratarata -2,608667 dengan standar deviasi 1,3332139. D. Variabel LN_Harga Saham memiliki sampel 60 dengan nilai minimum 3,9100 dan nilai maksimum 8,3700 sedangkan nilai rata-rata 6,311667 dengan standar deviasi 1,1290752.

\section{Hasil Uji Asumsi Klasik}

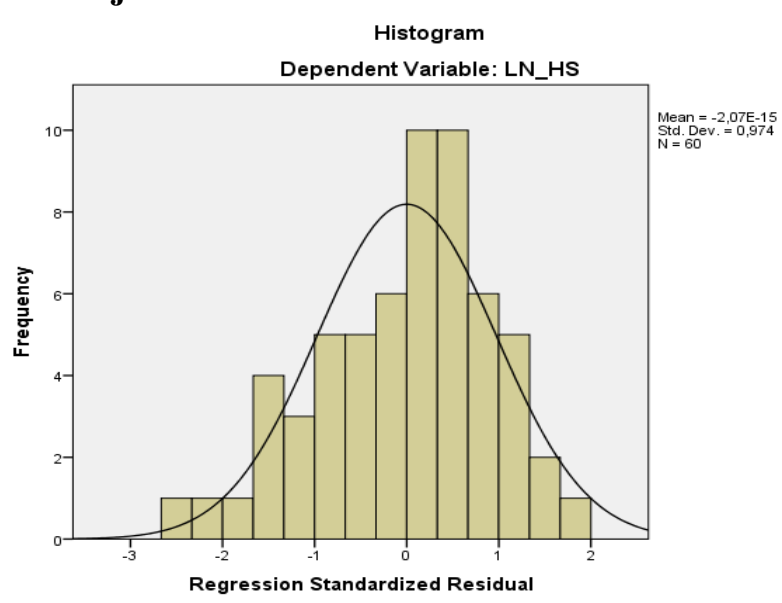

Gambar 1. Histogram

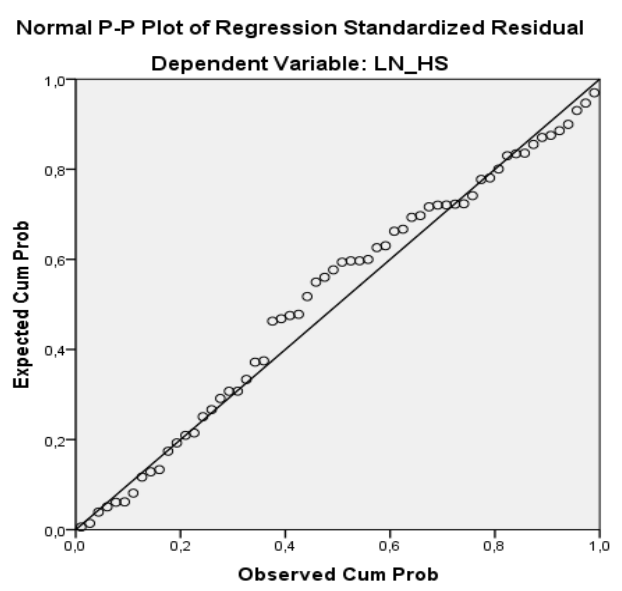

Gambar 2. Normal P-P Plot of Regression Standardized Residual

\section{Uji Normalitas}

Tabel 3. Komolgrov Simirnov One-Sample Kolmogorov-Smirnov Test

\begin{tabular}{|c|c|c|}
\hline & & $\begin{array}{c}\text { Unstandardized } \\
\text { Residual }\end{array}$ \\
\hline $\mathrm{N}$ & & 60 \\
\hline \multirow{3}{*}{ Normal Parameters ${ }^{\mathrm{a}, \mathrm{b}}$} & Mean & $0 \mathrm{E}-7$ \\
\hline & Std. Deviation & ,96313334 \\
\hline & Absolute &, 101 \\
\hline \multirow[t]{2}{*}{ Most Extreme Differences } & Positive & 045 \\
\hline & Negative &,- 101 \\
\hline Kolmogorov-Smirnov Z & &, 780 \\
\hline Asymp. Sig. (2-tailed) & &, 577 \\
\hline
\end{tabular}

a. Test distribution is Normal.

b. Calculated from data.

Sumber: Data diolah 
Berdasarkan hasil diatas One-Sample Kolmogorov-Smirnov Tes nilai kolmogorov Smirnov sebesar 0,780 dan Asymp. Sig. (2-tailed) 0,577 dan nilai tersebut lebih besar dari 0,05 , sehingga model residual terdistribusi secara normal.

\section{Uji Multikolonieritas}

Tabel 4. Uji Multikolonieritas

Coefficients $^{\mathrm{a}}$

\begin{tabular}{|c|c|c|c|c|c|c|c|c|}
\hline \multirow[t]{2}{*}{ Model } & & \multicolumn{2}{|c|}{ Unstandardized Coefficients } & $\frac{\text { Standardized Coefficients }}{\text { Beta }}$ & \multirow[t]{2}{*}{$\mathrm{t}$} & \multirow[t]{2}{*}{ Sig. } & \multicolumn{2}{|c|}{ Collinearity Statistics } \\
\hline & & $\mathrm{B}$ & Std. Error & Beta & & & Tolerance & VIF \\
\hline \multirow{4}{*}{1} & (Constant) & 6,962 & ,374 & & 18,603 & ,000 & & \\
\hline & LN_CR & ,734 & ,262 & ,393 & 2,808 & ,007 & ,664 & 1,505 \\
\hline & LN_DER & 1,189 & ,261 & ,657 & 4,559 & ,000 & ,625 & 1,599 \\
\hline & LN_NPM & ,131 & , 101 & ,155 & 1,295 & ,201 & ,907 & 1,103 \\
\hline
\end{tabular}

a. Dependent Variable: LN_HS

Sumber: Data diolah

Dari hasil uji diatas nilai tolerance value semua variabel independen berada diatas 0,10 yaitu sebesar 0,664 untuk LN_CR sebagai X1, 0,625 untuk LN_DER sebagai X2, 0,907 untuk LN_NPM sebagai X3. sedangkan nilai VIF antara variabel $\mathrm{X} 1, \mathrm{X} 2$ dan $\mathrm{X} 3$ berada di bawah 10. Jadi dapat disimpulkan bahwa penelitian ini berdasarkan nilai tolerance dan vif tidak terjadi multikolonieritas.

\section{Uji Autokorelasi}

Tabel 5. Uji Autokorelasi

Model Summary ${ }^{\text {b }}$

\begin{tabular}{|c|c|c|c|c|c|}
\hline Model & $\mathrm{R}$ & R Square & Adjusted R Square & Std. Error of the Estimate & Durbin-Watson \\
\hline 1 & $.522^{\mathrm{a}}$ & 272 & 233 & 9885950 & 1,897 \\
\hline
\end{tabular}

a. Predictors: (Constant), LN_NPM, LN_CR, LN_DER

b. Dependent Variable: LN_HS

Sumber: Data diolah

Dari hasil uji di atas diketahui nilai DW sebesar 1,897 nilai ini akan dibandingkan dengan nilai tabel dengan menggunakan nilai signifikansi 5\%. dengan niali DU sebesar 1,6889. Dengan ketetapan DU $<$ DW $<4-$ du
$1.6889<1,897<2,311$ dari hasil tersebut tidak terjadi autokorelasi dalam penelitian.

\section{Uji Heteroskedastisitas}

Tabel 6. Uji Heteroskedastisitas

\section{Coefficients}

\begin{tabular}{|c|c|c|c|c|c|c|}
\hline \multirow{3}{*}{\multicolumn{2}{|c|}{ Model }} & \multirow{2}{*}{\multicolumn{2}{|c|}{ Unstandardized Coefficients }} & & \multirow{3}{*}{$\mathrm{T}$} & \multirow{3}{*}{ Sig. } \\
\hline & & & & Standardized Coefficients & & \\
\hline & & $\mathrm{B}$ & Std. Error & Beta & & \\
\hline \multirow{4}{*}{1} & (Constant) & ,759 & ,214 & & 3,548 & ,001 \\
\hline & LN_CR &,- 008 & , 149 &,- 009 &,- 055 & ,956 \\
\hline & LN_DER & 081 & 149 & ,091 &, 541 &, 591 \\
\hline & LN_NPM &,- 032 & 058 &,- 076 &,- 545 &, 588 \\
\hline
\end{tabular}

a. Dependent Variable: RES2

Sumber: Data diolah

Dari hasil uji diatas didapatkan nilai SIG diatas 0,05 untuk Variabel LN_CR, LN_DER dan LN_NPM yang artinya semua variabel tidak mengalami masalah Heteroskedastisitas.

\section{Uji Regresi Linier Berganda}

Tabel 7. Uji Regresi Linier Berganda Coefficients $^{\mathrm{a}}$

\begin{tabular}{|c|c|c|c|c|c|c|}
\hline \multirow{2}{*}{\multicolumn{2}{|c|}{ Model }} & \multicolumn{2}{|c|}{ Unstandardized Coefficients } & \multirow{2}{*}{$\frac{\text { Standardized Coefficients }}{\text { Beta }}$} & \multirow[t]{2}{*}{$\mathrm{T}$} & \multirow[t]{2}{*}{ Sig. } \\
\hline & & $\mathrm{B}$ & Std. Error & & & \\
\hline \multirow{4}{*}{1} & (Constant) & 6,962 & ,374 & & 18,603 & 000 \\
\hline & LN_CR & ,734 & ,262 & ,393 & 2,808 & ,007 \\
\hline & LN_DER & 1,189 & 261 & 657 & 4,559 & 000 \\
\hline & LN_NPM &, 131 & 101 &, 155 & 1,295 & 201 \\
\hline
\end{tabular}


Dari hasil diatas diperoleh persamaan regresi sebagai berikut:

$\mathrm{Y}=\mathrm{a}+\mathrm{b} \times 1+\mathrm{b} \times 2+\mathrm{b} \times 3+\mathrm{e}$

$$
\mathrm{Y}=6,962+0,734 \times 1+1,189 \times 2+0,131 \times 3+\mathrm{e}
$$

\section{Uji Koefisien Determinasi}

Tabel 8. Uji Koefisien Determinasi

\section{Model Summary}

\begin{tabular}{lrrrrr}
\hline Model & $\mathrm{R}$ & $\mathrm{R}$ Square & Adjusted R Square & Std. Error of the Estimate \\
\hline 1 &, $522^{\mathrm{a}}$ & &, 272 & &, 233 \\
\hline
\end{tabular}

a. Predictors: (Constant), LN_NPM, LN_CR, LN_DER

Sumber: Data diolah

Dari hasil data diatas diperoleh nilai $\mathrm{R}$ square sebesar 0,272 atau 27,2\%. Yang artinya harga saham mampu menjelaskan variabel X1,X2, dan X3 .

Sedangkan sisanya $72,8 \%$ dijelaskan oleh variabel lain yang tidak diteliti dalam penelitian ini.

\section{Uji F}

Tabel 9. Uji F

ANOVA $^{\mathrm{a}}$

\begin{tabular}{llrrrrr}
\hline Model & & Sum of Squares & df & Mean Square & F & Sig. \\
\hline \multirow{2}{*}{1} & Regression & 20,484 & & 3 & 6,828 & 6,986 \\
& Residual & 54,730 & 56 &, 977 & & \\
& Total & 75,214 & 59 & & & \\
\hline
\end{tabular}

a. Dependent Variable: LN_HS

b. Predictors: (Constant), LN_NPM, LN_CR, LN_DER

Sumber: Data diolah

Dari hasil uji diatas diperoleh nilai $F_{\text {hitung }}$ sebesar 6,986 dengan $F_{\text {tabe }} 12,54$. Dan nilai signifikan sebesar 0,000 . Artinya nilai $6,986>2,54$ artinya variabel

independen berpengaruh secara simultan terhadap variabel dependen (harga saham

\section{Uji T}

Tabel 10. Uji $T$

Coefficients ${ }^{\mathrm{a}}$

\begin{tabular}{|c|c|c|c|c|c|c|}
\hline \multirow{2}{*}{\multicolumn{2}{|c|}{ Model }} & \multicolumn{2}{|c|}{ Unstandardized Coefficients } & \multirow{2}{*}{$\frac{\text { Standardized Coefficients }}{\text { Beta }}$} & \multirow[t]{2}{*}{$\mathrm{t}$} & \multirow[t]{2}{*}{ Sig. } \\
\hline & & $\mathrm{B}$ & Std. Error & & & \\
\hline \multirow{4}{*}{1} & (Constant) & 6,962 &, 374 & & 18,603 & ,000 \\
\hline & LN_CR & ,734 & ,262 & ,393 & 2,808 & ,007 \\
\hline & LN_DER & 1,189 & ,261 & 657 & 4,559 & 000 \\
\hline & LN_NPM & 131 & 101 &, 155 & 1,295 & 201 \\
\hline
\end{tabular}

a. Dependent Variable: LN_HS

Sumber: Data diolah

Hasil dari pembahasan Uji $\mathrm{T}$ adalah sebagai berikut. A. Secara parsial uji T untuk CR terhadap Harga Saham adalah nilai $\mathrm{T}_{\text {hitung }}$ sebesar 2,808 sedangkan nilai $\mathrm{T}_{\text {tabel }}$ sebesar 2.00324. Maka 2,808> 2,00324 dengan nilai signifikan $0,007<0,05$. Artinya $\mathrm{CR}$ memiliki pengaruh terhadap Harga Saham dan signifikan. B. Secara parsial uji T untuk DER terhadap Harga Saham adalah nilai $\mathrm{T}_{\text {hitung }}$ sebesar 4,559 sedangkan nilai $\mathrm{Tt}_{\text {abel }}$ sebesar 2.00324. maka 4,559>2,00324 dengan nilai signifikan $0,000<0,05$. Artinya DER memiliki pengaruh terhadap Harga Saham dan signifikan. C. Secara parsial uji T untuk NPM terhadap Harga Saham adalah nilai $\mathrm{T}_{\text {hitung }}$ sebesar 1,295 sedangkan nilai $\mathrm{T}_{\text {tabel }}$ sebesar 2.00324. maka $1,295<2,00324$ dengan nilai signifikan 0,201 >0,05. Artinya NPM tidak memiliki pengaruh terhadap Harga Saham dan tidak signifikan.

\section{Pembahasan}

Variabel Current Ratio menyatakan bahwa secara parsial berpengaruh dan signifikan terhadap Harga Saham. Hal ini juga didukung penelitian sebelumnya yang diteliti oleh Diarsyad (2018) yang dalam penelitian mereka menunjukkan bahwa Current Ratio berpengaruh terhadap harga saham dan berdampak signifikan. Dari hasil tersebut dapat disimpulkan bahwa investor dapat memprediksikan harga saham dengan mempertimbangkan Current Ratio untuk mengambil keputusan dalam berinvestasi. Kemampuan perusahaan dalam melunasi untang jangka pendeknya dengan tepat 
waktu dapat membuat prespektif yang baik dari investor kepada suatu perusahaan dan dengan adanya prespektif yang baik akan menjadi daya tarik untuk investor dalam berinvestasi, maka penawaran dan permintaan saham pun akan berdampak pada perubahan harga saham . Pernyataan diatas merupakan hasil penelitian yang didukung teori yang ada. menurut Brigham dan Houston (2018), Current Ratio merupakan rasio likuiditas yang menunjukkan sampai sejauh apa kewajiban lancar ditutupi oleh aset yang diharapkan akan dikonversi menjadi kas dalam waktu dekat.

Variabel Debt To Equity Ratio menyatakan bahwa secara parsial berpengaruh dan signifikan terhadap Harga Saham. Hal ini juga didukung penelitian sebelumnya yang diteliti oleh Putri Desi (2019) yang dalam penelitian mereka menunjukkan bahwa Debt To Equity Ratio berpengaruh terhadap harga saham dan berdampak signifikan. Dari hasil tersebut dapat disimpulkan bahwa penilaian investor terhadap hutang dapat dinilai dari cara perusahaan mampu mengelola hutangnya ataupun penggunaan hutang itu sendiri, sehingga investor dapat menilai positif keberadaan hutang tersebut jika dikelola dengan baik oleh perusahaan.

Pernyataan diatas merupakan hasil penelitian yang didukung teori yang ada., menurut Patriawan (2011), Debt To Equity Ratio merupakan rasio yang mengukur sejauh mana besarnya hutang yang dapat ditutupi oleh modal sendiri.

Variabel Net Profit Margin menyatakan bahwa secara parsial tidak berpengaruh dan tidak signifikan terhadap Harga Saham. Hal ini juga didukung penelitian sebelumnya yang diteliti oleh Walandouw (2017) yang dalam penelitian mereka menunjukkan bahwa Net Profit Margin tidak berpengaruh terhadap harga saham yang berarti tidak berdampak signifikan pada harga saham dan menunjukkan harga saham sebuah perusahaan tidak tergantung pada nilai Net Profit Margin. Hal ini bisa terjadi karena Net Profit Margin tidak mengukur kualitas dari laba yang dihasilkan, yaitu apakah laba yang dihasilkan didapatkan dari laba operasi atau laba yang lainnya. Pernyataan diatas merupakan hasil penelitian yang didukung teori yang ada. Menurut Hanafi dan Halim (2017), Net Profit Margin merupakan rasio yang menghitung sejauh mana kemampuan perusahaan menghasilkan laba bersih pada tingkat penjualan tertentu.

\section{SIMPULAN}

Berdasarkan hasil pembahasan sebelumnya pada perusahaan Trade Service and Investment di Bursa Efek Indonesia periode 2014-2018, dapat disimpulkan sebagai berikut. 1. Current Ratio berpengaruh secara parsial juga mengalami signifikan terhadap Harga Saham. 2. Debt to Equity Ratio berpengaruh secara parsial dan mengalami signifikan terhadap Harga Saham. 3. Net Profit Margin tidak berpengaruh secara parsial dan signifikan terhadap Harga Saham pada perusahaan Trade Service and Investment di Bursa Efek Indonesia periode 2014-2018. 4. Dari hasil pengujian yang dilakukan pada Current Ratio, Debt to Equity Ratio, dan Net Profit Margin terhadap Harga Saham, maka diketahui bahwa variabel-variabel tersebut berpengaruh secara simultan.

Beberapa saran yang dapat diberikan dari penelitian ini adalah. 1. Bagi perusahaan Trade Service and Investment, harusnya meningkatkan penjualan perusahaan sehingga dapat meningkatkan pendapatan dan keuntungan atau laba pada perusahaan sehingga dapat bertahan dan beroperasi untuk kesejahteraannya. 2 . Bagi Investor, untuk memperhatikan semua laporan keuangan yang ada pada perusahaan sehingga dapat membantu memilih dan melakukan investasi yang baik dan bermanfaat. 3. Bagi investor, agar mengalokasikan dana nya secara seimbang pada saham perusahaan, sehingga terhindar dari financial distress dan tentu saja demi memperoleh keuntungan semaksimal mungkin dan juga untuk mempertahankan labanya di masa yang akan datang. 4. Bagi Universitas Prima Indonesia, diharapkan bahwa penelitian ini dapat membantu dan memberikan kontribusi terhadap perkembangan pengetahuan untuk seluruh mahasiswa fakultas ekonomi.

\section{DAFTAR PUSTAKA}

Aditya, Pratama (2014). Pengaruh Current ratio, Debt to equity ratio, Return on equity ratio, net profit margin dan earning per share terhadap Harga saham (study kasus pada perusahaan manufaktur yang terdaftar di Bursa Efek Indonesia periode 2008-2011). Jurnal Akuntansi Universitas Sarjanawiyata Tamansiswa. Vol.2 No.1 Juni 2014.

Brigham, E.F. dan Houston, J.F. 2009. Dasar-Dasar Manajemen Keuangan. Edisi 10. Penerbit Salemba Empat. Jakarta.

Darsono dan Ashari. 2005. Pedoman Praktis Memahami Laporan Keuangan. Yogyakarta: CV. Andi Offset

Fahmi, Irham. 2016. Pengantar Manajemen Keuangan. Bandung: CV Alfabeta.

Ghozali, imam (2016). Aplikasi Analisis Multivariate dengan Program IBM SPSS 23. Ed. 8, Semarang : Badan penerbit Universitas Diponegoro.

Hanafi, Mamduh M dan Halim A. 2007. Analisis Laporan Keuangan, Edisi 3. UPP STIM YPKN, Yogyakarta.

Jae. K. Shim, and Joel G. Siegel, 2008, Financial Management, Barron Education Series Inc. New York

Kasmir. 2014. Analisis Laporan Keuangan. Edisi Satu. Cetakan Ketujuh. Jakarta: PT Raja Grafindo Persada 
Patriawan, Dwiatma. 2011. Analisis Pengaruh Earning Per Share (EPS), Return On Equity (ROE), dan Debt to Equity Ratio (DER) Terhadap Harga Saham Pada Perusahaan Wholesale and Retail Trade yang Terdaftar di Bursa Efek Indonesia (BEI) Tahun 20062008. Skripsi Sarjana Jurusan Ekonimi Fakultas ekonomi Universitas Diponegoro, Semarang.

Rico, L \& Winda A (2018). Pengaruh Struktur modal dan profitabilitas terhadap Harga saham. Jurnal Ekonomi dan Bisnis islam. Vol.3 No.1 Januari 2018.

Riris, Novitasari (2017). Pengaruh Current ratio (CR), Debt to equity ratio (DER), Return on assets (ROA), da2013-2016). Jurnal Administrasi Bisnis, Universitas Diponegoro, Indonesia.

Rosa, Yumisa Amrah dan Elwisam (2018). Pengaruh Current ratio, Return on assets, Debt to equity ratio, dan Total assets turnover terhadap Harga saham pada perusahaan LQ45 tahun 2013-2015. Jurnal Ilmu Manajemen Program Studi Manajemen Fakultas Ekonomi Universitas Nasional.

Samsul, Mohammad. 2006. Pasar Modal dan Manajemen Portofolio. Jakarta: Erlangga.

Sri, Beti Kumalasari (2017). Pengaruh Current ratio, Net Profit margin, Earning per share terhadap Harga saham pada perusahaan Manufaktur sektor Industri barang konsumsi yang terdaftar di BEI tahun 2013-2015. Skripsi Universitas Nusantara PGRI Kediri 2017.

Tri, Laksita Asmi (2014). Current ratio, Debt to equity ratio, Total asset turnover, Return on Asset, Price to book Value sebagai faktor penentu Return saham. Management analysis journal, Universitas Negeri Semarang, Indonesia 2014.

Vera, Ch. O. Manoppo (2017). Pengaruh Current Ratio, DER, ROA, dan NPM terhadap Harga Saham pada perusahaan Food And Beverages yang terdaftar di BEI (periode 2013-2015). Jurnal EMBA Vol.5 No.2 Juni 20n Return on equity (ROE) terhadap Harga saham. (Studi pada perusahaan Sub sektor Telekomunikasi yang terdaftar di Bursa Efek Indonesia periode 